\title{
Characterization of aerosol and cloud water at a mountain site during WACS 2010: secondary organic aerosol formation through oxidative cloud processing
}

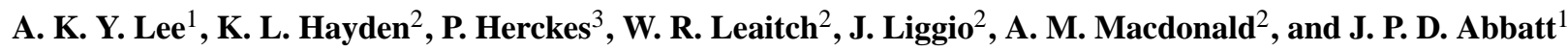 \\ ${ }^{1}$ Department of Chemistry, University of Toronto, Toronto, Canada \\ ${ }^{2}$ Science and Technology Branch, Environment Canada, Downsview, Canada \\ ${ }^{3}$ Department of Chemistry and Biochemistry, Arizona State University, Tempe, USA
}

Correspondence to: A. K. Y. Lee (klee@chem.utoronto.ca)

Received: 13 February 2012 - Published in Atmos. Chem. Phys. Discuss.: 24 February 2012

Revised: 25 June 2012 - Accepted: 15 July 2012 - Published: 6 August 2012

\begin{abstract}
The water-soluble fractions of aerosol filter samples and cloud water collected during the Whistler Aerosol and Cloud Study (WACS 2010) were analyzed using an Aerodyne aerosol mass spectrometer (AMS). This is the first study to report AMS organic spectra of re-aerosolized cloud water, and to make direct comparison between the AMS spectra of cloud water and aerosol samples collected at the same location. In general, the mass spectra of aerosol were very similar to those of less volatile cloud organics. By using a photochemical reactor to oxidize both aerosol filter extracts and cloud water, we find evidence that fragmentation of water-soluble organics in aerosol increases their volatility during photochemical oxidation. By contrast, enhancement of AMS-measurable organic mass by up to $30 \%$ was observed during the initial stage of oxidation of cloud water organics, which was followed by a decline at the later stages of oxidation. These observations are in support of the general hypothesis that cloud water oxidation is a viable route for SOA formation. In particular, we propose that additional SOA material was produced by functionalizing dissolved organics via $\mathrm{OH}$ oxidation, where these dissolved organics are sufficiently volatile that they are not usually part of the aerosol. This work demonstrates that water-soluble organic compounds of intermediate volatility (IVOC), such as cispinonic acid, produced via gas-phase oxidation of monoterpenes, can be important aqueous-phase SOA precursors in a biogenic-rich environment.
\end{abstract}

\section{Introduction}

Organic materials are one of the major constituents of atmospheric particulates (Jimenez et al., 2009; Zhang et al., 2007). Their formation mechanisms and properties, however, have not been fully understood, thus introducing uncertainties into current global climate models (IPCC, 2007). In particular, atmospheric models that predict secondary organic aerosol (SOA) formation via traditional gas-phase oxidation of biogenic and anthropogenic precursors followed by gas-particle partitioning of semi-volatile products cannot match the observed SOA mass loadings (e.g., Heald et al., 2010; Johnson et al., 2006; Volkamer et al., 2006). Moreover, the oxidation state of ambient SOA is usually higher than that of SOA produced from smog chamber experiments (Aiken et al., 2008; $\mathrm{Ng}$ et al., 2010). These observations suggest that there are unrecognized SOA sources.

Atmospheric aerosols can absorb water to become aqueous particles under humid conditions and activate to form cloud droplets upon water supersaturation. Because of the relatively high liquid water content in cloud and fog droplets, species in water-soluble organic carbon (WSOC) with high volatility which have not been considered as traditional SOA precursors, such as glyoxal, methylgloxal and other less oxygenated organics, may partition into the aqueous droplets ( $\mathrm{Fu}$ et al., 2008, 2009; Volkamer et al., 2009). Oligomerization and functionalization of these organics via aqueous-phase oxidation may generate low volatility products that can remain in evaporated droplets, forming additional SOA material (Blando and Turpin, 2000; Ervens et al., 2011; Gelencser

Published by Copernicus Publications on behalf of the European Geosciences Union. 
and Varga, 2005; Huang et al., 2011). Recent laboratory studies have shown that the major particle-phase products of aqueous $\mathrm{OH}$ oxidation of glyoxal and methylglyoxal include small organic acids and high molecular weight products with high oxygen-to-carbon $(\mathrm{O} / \mathrm{C})$ atomic ratio (Carlton et al., 2007; Lee et al., 2011b; Lim et al., 2010; Tan et al., 2009, 2010; Zhao et al., 2012). Bateman et al. (2011) found that photolysis of aqueous extracts of SOA derived from dark ozonolysis of d-limonene might generate $\mathrm{OH}$ radicals and the combined results of photo-dissociation and $\mathrm{OH}$ oxidation led to fragmentation of dissolved SOA materials with increasing O/C ratio. Chang and Thompson (2011) observed formation of visible light absorbing materials with similar IR spectral features to atmospheric humic-like substances (HULIS) via aqueous $\mathrm{OH}$ oxidation of phenolic compounds. Since the aerosol-cloud droplet conversions (i.e., cloud cycles) likely occur frequently within an air parcel, repeated repartitioning of such WSOC between the gas, aqueous and particle phases in the presence of aqueous oxidative processing may be an important source of highly oxygenated SOA components.

Oxalic acid, a highly oxidized organic formed via in-cloud processing (e.g., Ervens et al., 2004; Sorooshian et al., 2006, 2007), has been experimentally identified as an important aqueous oxidation product of many potential precursors under cloud-relevant concentrations (Perri et al., 2009; Tan et al., 2009, 2010, 2012). On the basis of aircraft measurements, Sorooshian et al. (2007) suggested that the source of oxalic acid in aerosol particles above cloud was a result of aqueous-phase processing, in which oxalic acid formation was shown to be enhanced with increasing amounts of both liquid water content and $\mathrm{pH}$ in droplets. A recent modeling study also concluded that in-cloud processing could explain the observed oxalate concentration in both rural and remote locations (Myriokefalitakis et al., 2011). SOA formation in aerosol water is also possible. Hennigan et al. (2008) measured both gas-phase and particulate WSOC during the summertime of Atlanta and observed a sharp increase of WSOC in particulate fraction at elevated relative humidity, suggesting a positive correlation with aerosol liquid water. Because of the limited water content in fine particles, Henry's law partitioning alone cannot explain the SOA enhancement observed by Hennigan et al. (2008), and thus subsequent aqueous chemistry of dissolved organics that further drives the Henry's law partitioning in aerosol particles likely took place. Furthermore, Kaul et al. (2011) recently reported that aqueous-phase processing likely enhanced the production of SOA in foggy periods in Kanpur, India. To explain a missing sink of glyoxal in Mexico City, .Volkamer et al. (2007) suggested that SOA formation from glyoxal in aqueous particles could contribute up to $15 \%$ of total organic aerosol mass.

Although there is growing evidence that extra and more oxidized SOA can be produced via aqueous oxidative processing, the relevant reaction mechanisms and potential organic precursors in the atmospheric aqueous phase are still not well understood. In this study, we investigate the chem- ical characteristics of WSOC in aerosol filter extracts and cloud water collected at Whistler, British Columbia during the summer 2010 - Whistler Aerosol and Cloud Study (WACS 2010). The term "cloud water" used in this paper refers to the cloud droplets approaching our forest mountain sites and we assume it has similar composition to the cloud, at the same elevations, that did not impact the mountain. The aqueous samples were atomized and the chemical composition of dried aerosol particles was subsequently analyzed by an Aerodyne aerosol mass spectrometer (AMS). Aqueous-phase $\mathrm{OH}$ oxidation of aerosol filter extracts and cloud water was performed using a photochemical reactor that allows simultaneous photo-oxidation and mass spectrometry measurement of aerosolized organics using an AMS (Lee et al., 2011a, b). Noting that because AMS only measures condensed-phase materials but not volatile organics, this experimental approach qualitatively simulates aqueous oxidative aging in the bulk aerosol and cloud droplets, followed by evaporation of water and volatile organics to form SOA. The primary goal of this study is to investigate whether aqueous-phase $\mathrm{OH}$ oxidation of ambient organics can be an additional source of SOA. The experimental results provide insights into aqueous oxidation mechanisms, especially the competition between the functionalization and fragmentation channels, of organic aerosols and cloud organics, and may help to identify potential aqueous-phase SOA precursors in a biogenic-rich environment.

\section{Experiment}

\subsection{Aerosol and cloud water samples collection}

To better understand aqueous oxidative processing of WSOC in SOA and cloud organics, aerosol filter samples and cloud water were collected at Whistler, British Columbia, during summer 2010 for chemical characterization and performing aqueous oxidation experiments (see details in Section 2.2). The sampling site for aerosol collection was Raven's Nest (RN) which sits within a coniferous forest mountain area at an elevation of $1300 \mathrm{~m}$ a.s.l. The ambient aerosols passed through a cyclone with PM1 cut size (UGR, Model 463) and were collected on $47 \mathrm{~mm}$ Teflon filters ( $2.0 \mu \mathrm{m}$ pores) for 24 hours. A possible negative sampling artifact is that volatile and semi-volatile organic species in the aerosol phase may escape to the gas phase via evaporation. An Aerodyne High Resolution AMS (HR-AMS) was also employed at the RN site to measure real-time aerosol chemical composition throughout the campaign for comparison with aerosol composition in filter samples. The mass resolving power of the HR-AMS in our measurement was about 4000. The cloud water samples were collected by automated versions of the Caltech Active Stand Cloudwater Collector (CASCC) (Hutchings et al., 2009; Macdonald et al., 2012) at RN and also at another site at the Whistler mountain peak (peak site), 
located at an elevation of $2182 \mathrm{~m}$ a.s.l. Particle volume monitors Gerber PVM-100 (Gerber, 1991) were used to measure the cloud liquid water content (LWC) at the two sites for automated triggering of cloud water collection. The cloud collection was initiated when the LWC reached a threshold value. Six cloud water samples were analyzed from $\mathrm{RN}$ and only one was from the peak site.

In addition, a ground-based counter-flow virtual impactor (CVI) from the University of Stockholm was installed at the peak site (Noone et al., 1988; Macdonald et al., 2012). The CVI allows real-time measurement of cloud residuals using different online aerosol particle instruments by switching normal ambient inlets to the CVI output during cloud periods. This ground-based CVI selects droplets based on their inertia, created by a high vacuum intake flow, relative to a warm dry counter flow volume of air. In this case, droplets/particles larger than about $5 \mu \mathrm{m}$ diameter were sampled by the CVI and smaller cloud droplets and interstitial particles were expelled. The sampled droplets were dried in the CVI inlet and the non-refractory composition of cloud residuals was measured by a compact time of flight-AMS with unit mass resolution (CToF-AMS). The CVI only operated during cloud events and another inlet was used to sample ambient aerosol particles during pre- and post-cloud periods. In this study, the AMS organic spectra of cloud residual (09:06-10:51 PST) and aerosol particles during pre- and post-cloud period (02:36-03:48 and 13:15-13:45) on 22 July are discussed.

\subsection{AMS characterization and photo-oxidation of aqueous samples}

The aerosol filter samples were extracted in about $30 \mathrm{~mL}$ of purified water $(18 \mathrm{M} \Omega \mathrm{cm})$ and the cloud water was filtered before analysis. The estimated total organic concentration of aerosol filter extracts was on the order of $10^{-5} \mathrm{M}$ based on the organic aerosol mass loading measured by the HR-AMS, assuming their average molecular weight of about $200 \mathrm{~g} \mathrm{~mol}^{-1}$ and that all the material was water soluble. The water-soluble fraction of ambient aerosols in aqueous extracts and filtered cloud water samples was atomized by compressed air on site using a TSI atomizer (Model 3076). The aqueous particles passed through a diffusion dryer and were subsequently analyzed by the CToF-AMS for determination of their non-refractory composition including sulfate, nitrate, ammonium and organics. The working principle of the AMS has been reviewed by Canagaratna et al. (2007). The standard fragmentation table with the corrected air fragment column for our carrier gas and the default values of relative ionization efficiency were used in the AMS data analysis (Squirrel, version $1.50 \mathrm{~b}$ ). Some of the aqueous samples were oxidized for 10 minutes using a custom-made photochemical reactor with an ozone-free $\mathrm{Hg}$ lamp (UVP, $254 \mathrm{~nm}$ ) (Lee et al., 2011a, b). The small glass tube with a volume of about $30 \mathrm{~mL}$ was inserted to the reaction glass vessel $(\sim 100 \mathrm{~mL})$ for holding the aqueous solution samples. Photolysis of $\mathrm{H}_{2} \mathrm{O}_{2}$ with initial concentration of about $70 \mathrm{mM}$ was used to produce aqueous $\mathrm{OH}$ radicals. We estimated the steady state $\mathrm{OH}$ radical concentration to be about $10^{-11} \mathrm{M}$ using a simple chemical model with a calculated $\mathrm{H}_{2} \mathrm{O}_{2}$ photolysis rate constant of $6.9 \times 10^{-4} \mathrm{~s}^{-1}$ (see details in supplementary material). Based on the control experiments performed in our laboratory, other potential photolytic sources of $\mathrm{OH}$ radicals were assumed to be negligible due to the high initial concentration of $\mathrm{H}_{2} \mathrm{O}_{2}$. We also assumed that the oxidative potential of $\mathrm{H}_{2} \mathrm{O}_{2}$ did not significantly affect the organic composition because the organic spectra of the oxidized solution remained roughly constant in a dark condition for about $1 \mathrm{~h}$. Because the reaction vessel allows atomization during the photo-oxidation processing, the composition changes of the reacting solution were monitored continuously by the CToF-AMS. With the aerosol drying process prior to the AMS measurement, the experimental setting qualitatively simulates aqueous oxidation in the bulk aerosol or cloud droplets followed by evaporation of water and volatile organics to form SOA.

To determine the background organic level contributed from water that was used for filter extraction, we atomized a few blank water samples and quantified their organic level using the experimental approach described above. Because of the low organic aerosol loading within the pre-biogenic period, a few aerosol filter extracts with total organic levels comparable to the background organic level of blank water were excluded from our data analysis. Eleven aerosol filter extracts with organic loadings at least 5 times higher than the average of the background organic level were included in the analysis. Note that it is not straight forward to subtract the spectra of water blanks from aerosol filter samples because the aerosol loadings measured by the CToF-AMS in each experimental run depend on the atomizer output as well as solute concentration. Due to the limited sample volume of aerosol filter extracts and cloud water, the effects of direct photolysis on our measurement were not examined. However, we believe that the organic composition of the reacting solution was mainly modified by $\mathrm{OH}$ oxidative reaction under such a high level of oxidant. Oxidation of water blanks were performed in the laboratory after the field campaign and there was no significant changes in organic loading.

\section{Results and discussion}

\subsection{Chemical composition of aerosol and cloud water}

The daily average composition profiles (sulfate, nitrate and organic mass fraction) of ambient particulate matter measured by HR-AMS at RN are shown in Fig. 1a. The details of aerosol characteristics and meteorological conditions at both sampling sites have been reported in the overview paper of the WACS 2010 campaign (Macdonald et al., 2012). In brief, the filter sample collection period can be roughly 

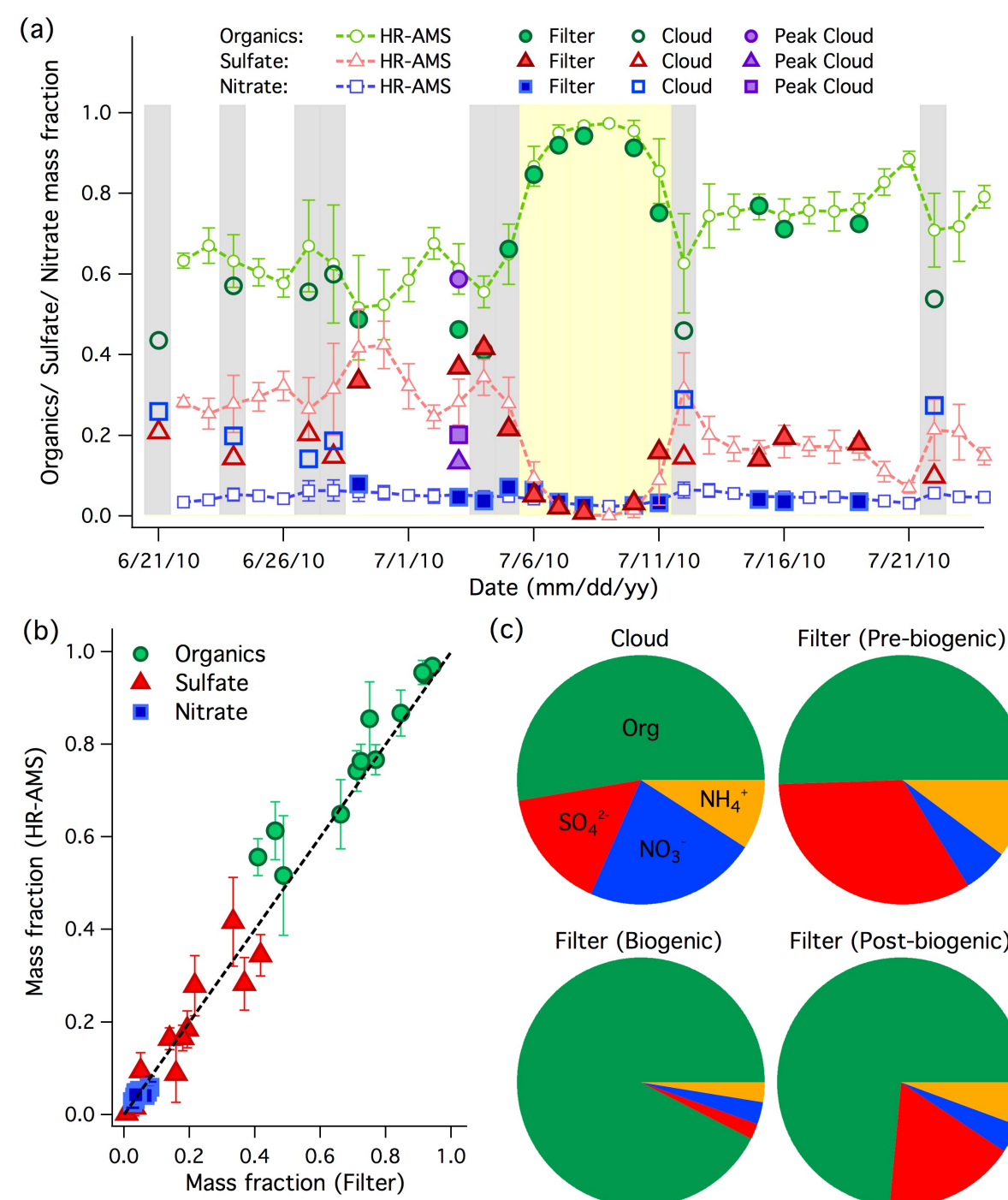

(c)
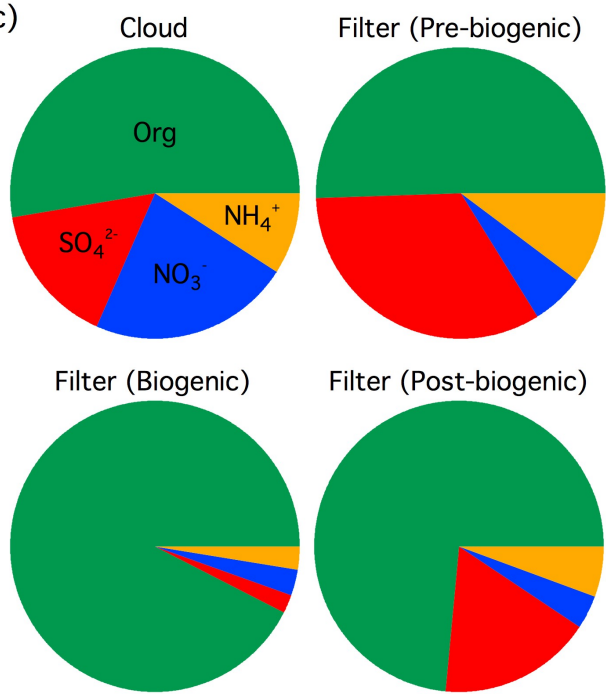

Fig. 1. (a) Chemical composition (sulfate, nitrate, and organics mass fraction) profile of ambient aerosol measured by online HR-AMS, aerosol filter samples at RN, and cloud water samples collected at both RN and peak sites. The biogenic episode is indicated by the yellow shaded region (6-11 July). The in-cloud days at RN are indicated by the grey shaded regions. (b) Correlations between chemical compositions of ambient aerosol measured by online HR-AMS at RN and those of re-aerosolized filter aerosol extracts at the same site. (c) Average chemical compositions of cloud water and water-soluble fraction of aerosol filter samples collected during the pre-biogenic, biogenic and post-biogenic periods at $\mathrm{RN}$.

divided into three different phases namely pre-biogenic $(21$ June-6 July), biogenic (6-11 July, yellow shaded region in Fig. 1a) and post-biogenic (11-22 July) period. Note that the WACS 2010 also covered a period with a significant influence of biomass burning (23-29 July), which is outside our filter sampling period. The biogenic period was well defined by a sustained high-pressure system over the region with cloud-free and high temperature conditions. During the biogenic period, SOA increased to a maximum of $\sim 6 \mu \mathrm{g} \mathrm{m}^{-3}$ at $\mathrm{RN}$ mainly due to photochemical oxidation of gas-phase biogenic precursors such as $\alpha$-pinene and isoprene emitted from the regional forest mountain area (Macdonald et al.,
2012). The in-cloud days at $\mathrm{RN}$ are shaded in grey as shown in Fig. 1a.

Figure 1a and $\mathrm{b}$ demonstrate that the overall chemical composition of the water-extractable fraction of aerosol filter samples is in good agreement with that measured simultaneously by HR-AMS at RN. Although the evaporative loss of semi-volatile species during sample collection, filter extraction, and droplet evaporation prior to AMS analysis was possible, this observation implies that most of the PM1 organics at RN were water extractable and able to be detected by the AMS after re-atomization. The average compositions of aerosol filter extracts are shown in Fig. 1c. 
In the pre-biogenic period, inorganic components accounted for $50 \mathrm{wt} \%$ of the water-soluble materials with sulfate as the main contributor. The WSOC rapidly increased to over $85 \mathrm{wt} \%$ within the biogenic period. Extremely low sulfate content in aerosol extracts $(<5 \%$ in general) indicates that the aerosol composition was not significantly influenced by anthropogenic sources. During the post-biogenic period, the organic fraction was sustained at about $70 \mathrm{wt} \%$ of the watersoluble materials, which was much higher than that observed in the pre-biogenic period, indicating that biogenic SOA production may have influenced the organic aerosol composition during this period.

Organics contributed about $50 \mathrm{wt} \%$ of cloud water constituents but this is likely a lower limit because of the presence and potential loss of volatile organics. The high water content in cloud droplets favors partitioning of watersoluble, volatile species into the aqueous phase. For example, C1-C5 carbonyl including formaldehyde, acetaldehyde, glyoxal, methylglyoxal, propionaldehyde and isovaleraldehyde already accounted for 8-30\% of water-soluble organic carbon in cloud samples collected at Whistler based on the results of offline analysis (Wang et al., 2012). Small carboxylic acids such as formic and acetic acid are also commonly found in cloud water (e.g. Munger et al., 1989). In addition to small carbonyls and organic acids, a predominance of pinonaldehyde, one of the major gaseous products of monoterpene oxidation, was observed in rainwater at central Japan (Satsumabayashi et al., 2001), providing evidence that cloud droplets can also absorb biogenic volatile organic compounds (VOC) with limited solubility in water. Although formation of less volatile and stable organic salts (e.g., dicarboxylates) and oligomers from these volatile species during droplet evaporation were possible (Loeffler et al., 2006; De Haan et al., 2009), the observed organic mass accounts for the potential effects from such reactions throughout the oxidation process. It is believed that a portion of volatile species may not be retained in the evaporated droplets and hence cannot be fully detected by the AMS. In the following discussion, low-volatility cloud water organics (LV-CWO) refer to AMS-measurable cloud organics and volatile cloud water organics (V-CWO) refer to high vapor pressure cloud organics that are not retained in the residuals of evaporated droplets for AMS detection.

The AMS results show that nitrate mass was comparable to sulfate mass in the cloud water samples, consistent with the results obtained from conventional analytical methods (Wang et al., 2012), whereas sulfate was the dominant inorganic in the aerosol filter samples collected within the non-biogenic period. The averages of nitrate-to-sulfate $\left(\left[\mathrm{NO}_{3}^{-}\right] /\left[\mathrm{SO}_{4}^{2-}\right]\right)$ mass ratios of cloud water and aerosol filter extracts collected within the non-biogenic period were approximately 1.4 and 0.2, respectively. Similarly, Hayden et al. (2008) reported that the $\left[\mathrm{NO}_{3}^{-}\right] /\left[\mathrm{SO}_{4}^{2-}\right]$ mass ratios of bulk cloud water (ranged from 0.6 to 7.1) were much higher than those of the below-cloud aerosols (ranged from 0.02 to 0.69 ) based on summer aircraft measurements near Cleveland, Ohio as part of ICARTT 2004. Ammonium ion contributed about $13 \%$ and $8 \%$ of aerosol filter extracts and cloud water constituents as shown in Fig. 1c. Previous laboratory studies have suggested that ammonium ion can catalyze the formation of oligomers from glyoxal or organic-nitrogen compounds in bulk solution (Noziere et al., 2009; Yu et al., 2011) and participate in complex chemistry to produce organic-nitrogen compounds in the particle phase processing (Galloway et al., 2009; De Haan et al., 2011; Nguyen et al., 2012). A large fraction of ammonium ion may thus reduce the overall volatility of organics in the evaporated droplets. Unfortunately, our CToF-AMS measurement with unit mass resolution cannot discriminate between the fragments of organic carbon and organic nitrogen that form as a result.

\subsection{Spectral characteristics of aerosol and cloud water organics}

The average AMS organic spectra of WSOC in aerosol filter samples are shown in Fig. 2a-c. The spectral features observed throughout the campaign are almost identical. The main exception is that the fresh biogenic SOA formed during the biogenic episode (Fig. 2b) has a relatively higher mass fraction intensity at $m / z 43(f 43)$ and lower $f 44$ than the SOA collected in the pre- and post-biogenic periods (Fig. 2a and c). While the organic fragment at $m / z 44\left(\mathrm{CO}_{2}^{+}\right)$is primarily due to the fragmentation of organic acids (e.g., Duplissy et al., 2011), $m / z 43$ of oxygenated organic aerosol mostly originates from $\mathrm{C}_{2} \mathrm{H}_{3} \mathrm{O}^{+}$(e.g., $\mathrm{Ng}$ et al., 2010), indicating the presence of less oxygenated functional characteristics. The above organic fragment assignment is also supported by our online HR-AMS measurement. Figure 3a, showing the time series profiles of $f 43$ and $f 44$ of the aqueous filter extracts, demonstrates that the biogenic time period is characterized by lower $f 44$-to- $f 43$ ratios, indicating these particles are less oxygenated than the aged SOA in the preand post-biogenic period at Whistler. This supports the hypothesis that atmospheric aging increases the degree of oxygenation of organic aerosol.

Figure $2 \mathrm{~d}$ and $\mathrm{f}$ show the average AMS organic spectra of LV-CWO in cloud water collected at RN (except the sample collected on 12 July) and peak sites, respectively. The spectral characteristics of LV-CWO collected at both sites are similar to each other and to those of WSOC in aerosol filter samples collected during the non-biogenic period $\left(\mathrm{R}^{2}\right.$ of the linear regression between the organic spectra $>0.9$ ). Nevertheless, the cloud water collected immediately after the biogenic episode (July 12) at RN has noticeably stronger $f 29$ intensity and a lower $f 44$-to- $f 43$ ratio than the other cloud samples, as shown in Figs. 2e and 3a. Our HR-AMS data suggests that $\mathrm{CHO}^{+}$fragment was the main contributor to organic fragments at $m / z 29$, likely due to the increased concentration of carbonyl functional groups. Physical uptake of water-soluble gaseous carbonyls, actively produced 
(a)

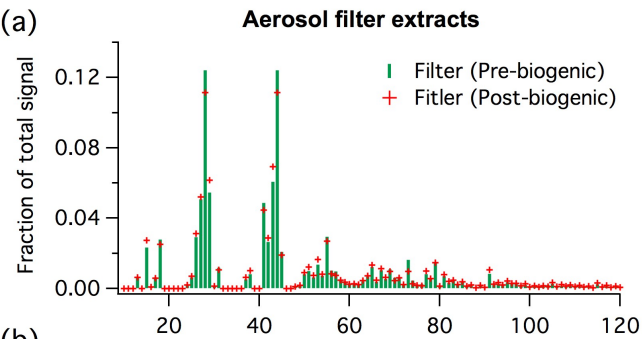

(b)

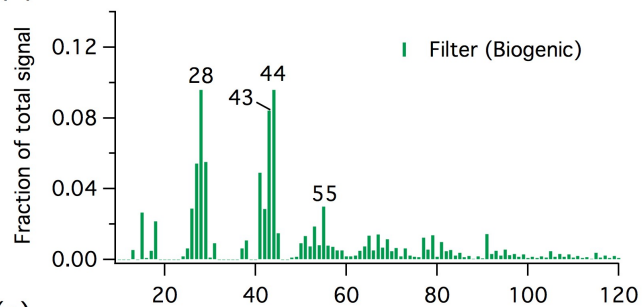

(c)

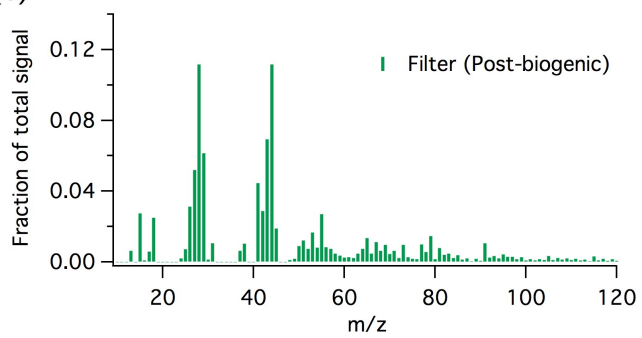

(g)

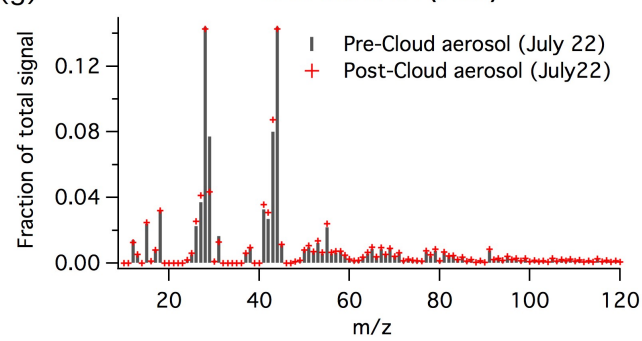

(d)

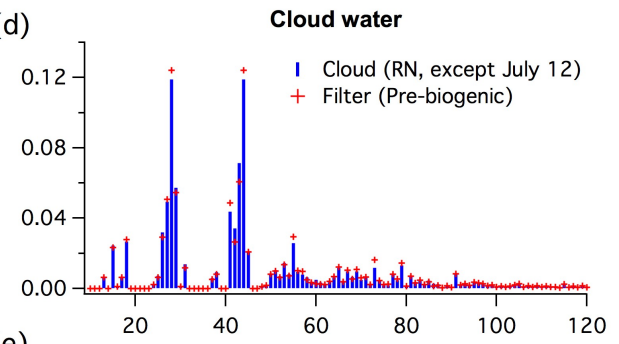

(e)

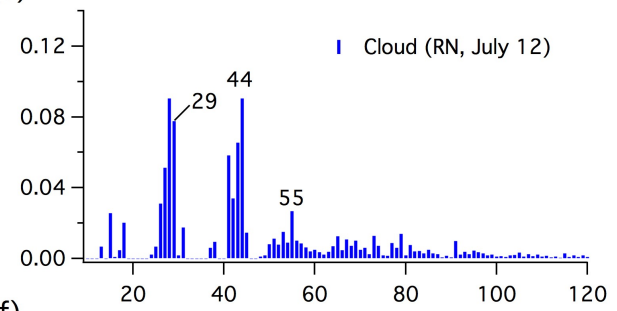

(f)

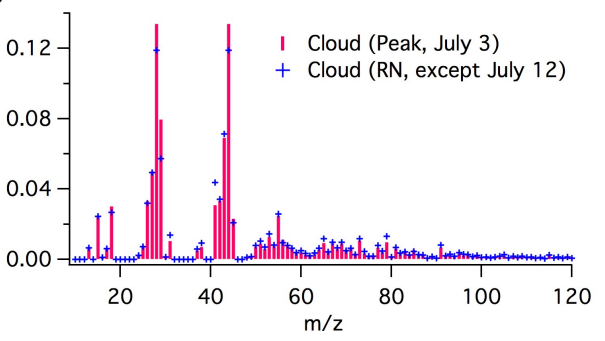

(h)

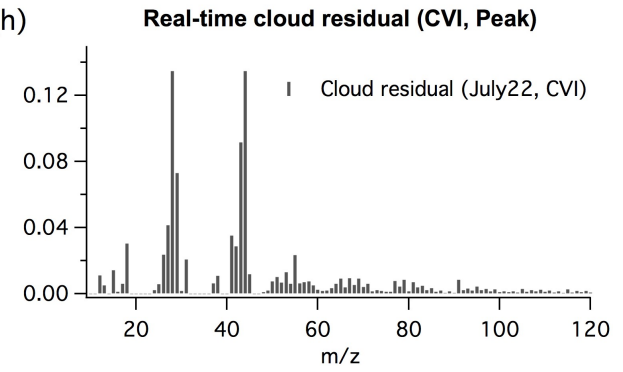

Fig. 2. Average AMS organic spectra (normalized by AMS organic mass) of aerosol filter extracts (a-c), cloud water (d-f), real-time PM1 in pre- and post-cloud period (g) and real-time cloud residuals at the peak sites (h). The cloud water collected on 12 July at RN has much higher intensity at $m / z 29$ compared to all other cloud water samples and thus it is not included in the average organic spectrum of cloud water (d).

in the biogenic episode, and oxidative aging of cloud organics could give rise to this observation (see later discussion). For example, based on our lab studies, glyoxal, methylglyoxal and propionaldehyde, all highly water-soluble carbonyls commonly found in cloud water, can give strong organic signals at $m / z 29$ and/or 43 but low organic signals at $m / z 44$ and other large fragments in their AMS spectra. Pyruvic acid, a product of aqueous oxidation of methylglyoxal (Tan et al., 2010), has comparable organic intensities at $\mathrm{m} / \mathrm{z} 43$ and 44 in its AMS spectrum.

Our real-time AMS measurement also shows that the organic spectra of cloud residuals sampled by the CVI are very similar to those of ambient aerosol particles analyzed during pre- and post-cloud period at the peak site $\left(\mathrm{R}^{2}\right.$ of the linear regression between the organic spectra $>0.9$ ) as shown in
Fig. $2 \mathrm{~g}$ and $\mathrm{h}$ (22 July). Similar to the re-atomization process of cloud water, sampling cloud residuals via the CVI would result in evaporation of $\mathrm{V}-\mathrm{CWO}$ from the cloud droplets and hence, only LV-CWO would be retained in the condensedphase and subsequently measured by the AMS. On the basis of all organic spectra obtained in this study (Fig. 2a-h), it can be concluded that the overall spectral features of aerosol and cloud droplets at Whistler are very similar to each other.

To better understand the characteristics of atmospheric organic aerosol, $\mathrm{Ng}$ et al. (2010) analyzed a worldwide AMS dataset on an $f 44$ vs. $f 43$ space. The global ambient organic aerosol predominately cluster inside a triangular region in the space, which is indicated by the dashed line bounded area in Fig. 3b. While semi-volatile oxygenated organic aerosols (SV-OOA or less oxidized OOA) mainly reside in the lower 

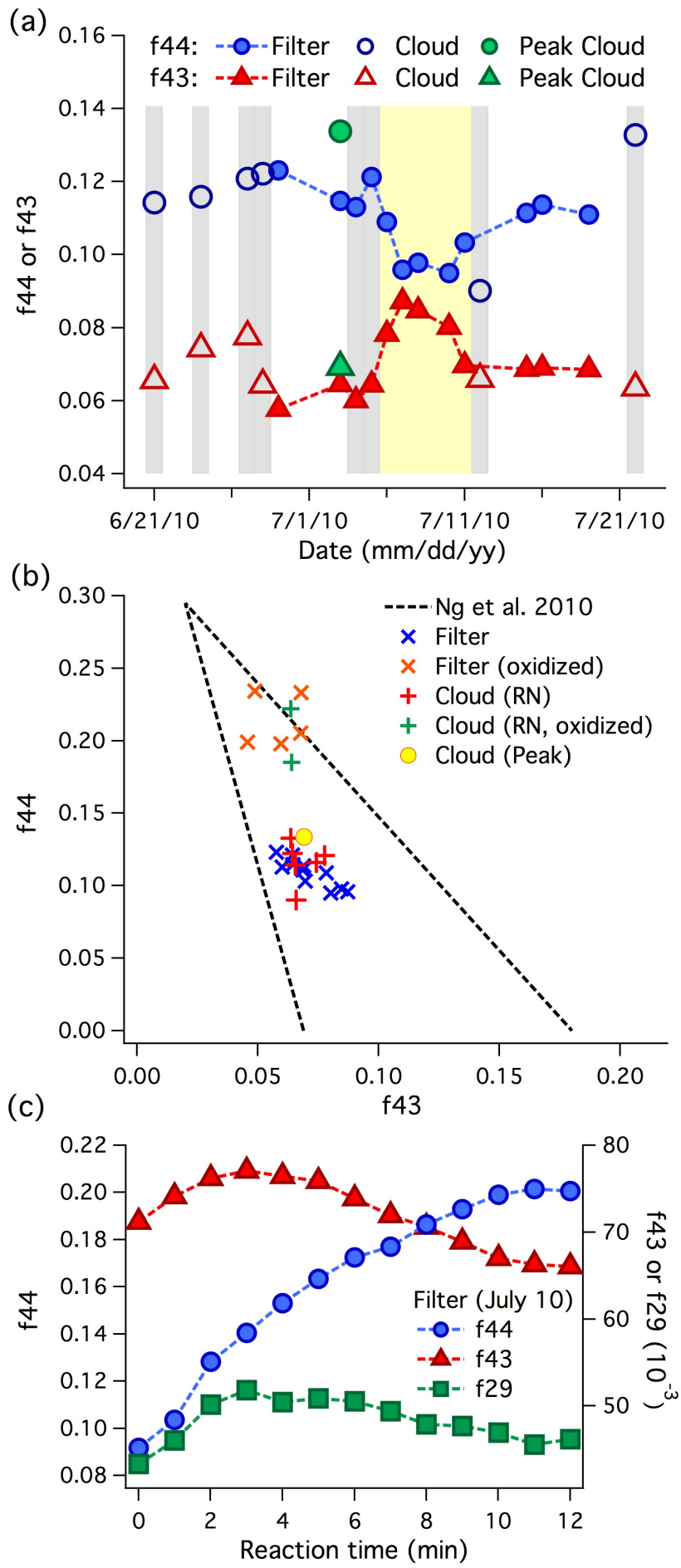

Fig. 3. (a) The $f 44$ and $f 43$ profiles of aerosol filter extracts and cloud water samples, (b) Coordinates of aerosol filter and cloud water samples before and after aqueous-phase $\mathrm{OH}$ oxidation on the $f 44$ vs. $f 43$ space. The worldwide ambient datasets mainly distributed within the dash line bounded triangular region $(\mathrm{Ng}$ et al., 2010). (c) The typical $f 44, f 43$, and $f 29$ profiles of filter aerosol extracts during oxidation (10 July sample). half of the triangular region, low-volatility OOA (LV-OOA or more oxidized OOA) concentrate in the upper half. The WSOC in the filter samples and the LV-CWO mainly fall in the transition zone of ambient SV-OOA and LV-OOA components. Based on the correlation established by Aiken et al. (2008), the $f 44$ value can be used as a surrogate to estimate the $\mathrm{O} / \mathrm{C}$ ratio of ambient organic aerosols. The estimated $\mathrm{O} / \mathrm{C}$ ratios of the WSOC in aerosol filter samples ranged from 0.44 to 0.50 and from 0.50 to 0.55 in the biogenic and non-biogenic periods, respectively. The estimated $\mathrm{O} / \mathrm{C}$ ratios of LV-CWO were between 0.52 and 0.59 , but it is not known whether the Aiken et al. (2008) relationship is valid for all products from aqueous-phase processing. In general, the $\mathrm{O} / \mathrm{C}$ ratios of our aerosol and cloud water samples are higher than those of chamber SOA produced by gasphase oxidation chemistry as summarized in some previous studies (e.g., Aiken et al., 2008; Chhabra et al., 2010; Ng et al., 2011) but much lower than those obtained from aqueous SOA oxidation and glyoxal uptake experiments (Lee et al., 2011a; Lambe et al., 2011; Chhabra et al., 2010). Note that the $\mathrm{O} / \mathrm{C}$ ratios of aerosol filter samples collected within the biogenic period are comparable to those measured from the Amazon Basin (0.42-0.49) (Chen et al., 2009), which is also strongly influenced by biogenic sources.

\subsection{Aqueous oxidation of aerosol and cloud water organics}

Figure $3 \mathrm{~b}$ also shows the results for aqueous $\mathrm{OH}$ oxidation of filter extracts and cloud water. All the resulting organics have a higher degree of oxygenation (estimated O/C ratios ranged from 0.79 to 0.98 ) than the original samples and have coordinates closer to that of global LV-OOA on the $f 44$ vs. $f 43$ space. This observation suggests that aqueous-phase chemistry is potentially important to produce atmospheric LV-OOA, in addition to traditional gas-phase chemistry and heterogeneous oxidation ( $\mathrm{Ng}$ et al., 2010). The typical $f 44$, $f 43$ and $f 29$ kinetic profiles of the oxidizing filter extracts are shown in Fig. 3c as an illustration. During the aqueous oxidation, the $f 44$ intensity of filter extracts and cloud water rise continuously, caused by increasing contribution of organic acids to total organic mass. The two-step kinetic behavior of $f 43$ and $f 29$ for both sample types suggest that less oxygenated carbonyls are likely condensed-phase intermediates that are subsequently converted to organic acids and volatile species in the reacting solution (Lambe et al., 2011; Lee et al., 2011a; Lim et al., 2010). Note that aqueous oxidation of $c i s$-pinonic acid and laboratory-generated $\alpha$-pinene SOA give similar kinetic profiles of these organic fragments (Lee et al., 2011a).

Figure $4 \mathrm{a}$ and d display the organic spectra of an aerosol filter extract (10 July) and cloud water (12 July) measured at the end of aqueous oxidation, and they also look similar to each other. The spectral differences between the AMS organic spectrum of an unoxidized sample and that of the 

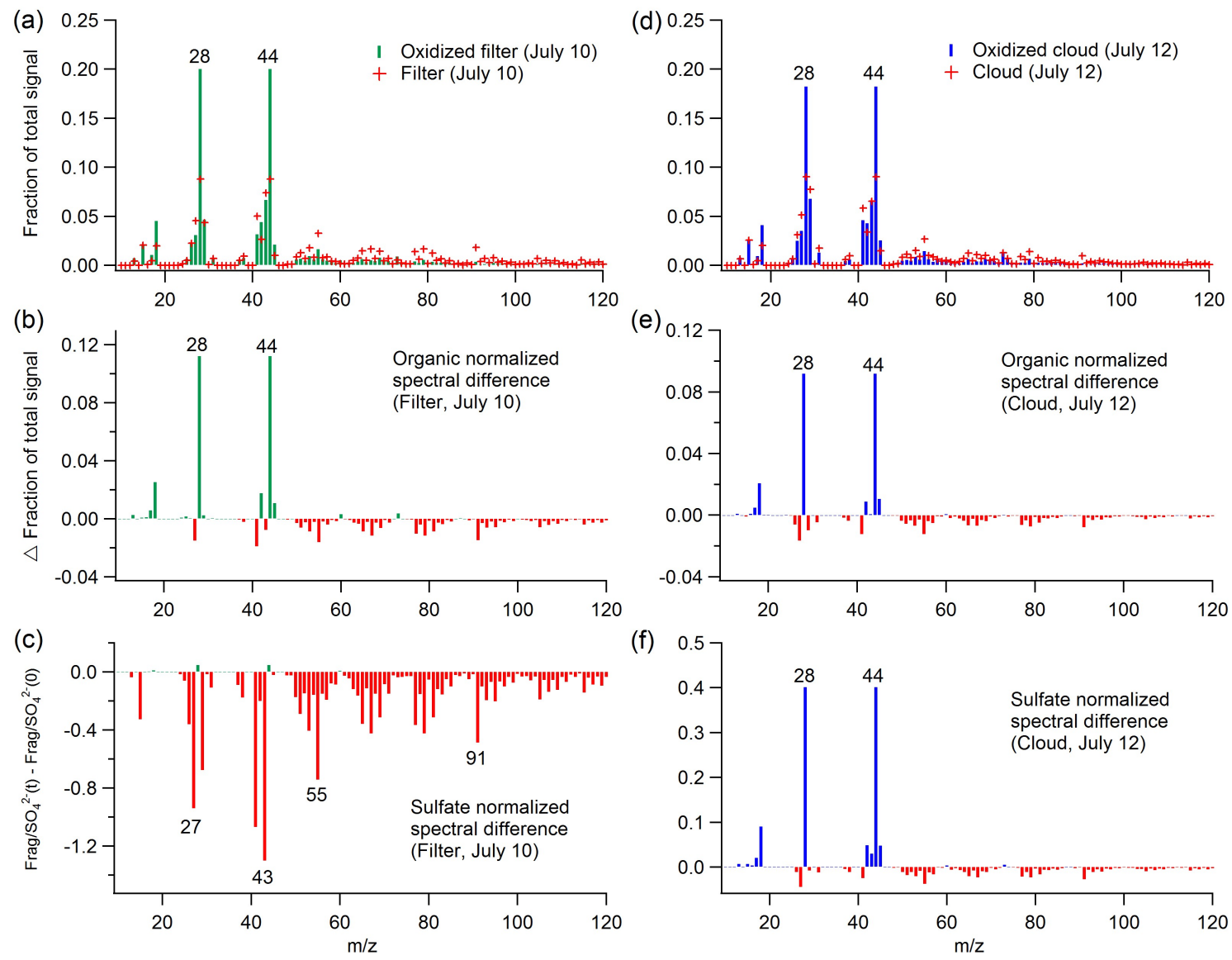

Fig. 4. Top spectra: AMS organic spectra of (a) aerosol filter extracts and (d) cloud water before and after aqueous-phase OH oxidation. Middle spectra: Spectral difference between the AMS organic spectra (normalized by AMS organics mass) of oxidized and un-oxidized (b) aerosol filter extracts and (e) cloud water. Bottom spectra: Spectral difference between the AMS organic spectra (normalized by sulfate mass) of oxidized and un-oxidized (c) aerosol filter extracts and (f) cloud water. Negative values (red) shown in (b), (c), (e) and (f) indicate that the mass fragments were consumed due to aqueous-phase $\mathrm{OH}$ oxidation.

corresponding oxidized sample for both sample types are shown in Fig. $4 b$ and e. Note that the spectra used for this subtraction were normalized to their corresponding total AMS organic mass so that the spectral difference only represents the fractional changes in organic composition. The differences of both sample types are almost identical. Most of the organic mass fragment signals decline with oxidation (displayed as negative differences), due to the consumption of starting material whereas only the strong positive differences are at $f 44$ and some other related fragments (e.g. $f 18$ and $f 28$ ), indicating that organic acids are the predominant condensed-phase products retained in the evaporated droplets within the timescale of our oxidation experiments. Note that the organic intensities at $m / z 28\left(\mathrm{CO}^{+}\right)$and $m / z 18$ $\left(\mathrm{H}_{2} \mathrm{O}^{+}\right)$are directly estimated from $m / z 44$ signals using the standard fragmentation table in Squirrel so that their changes cannot provide extra information for identifying the functional characteristics of oxidation products.
It is important to note that the spectral differences obtained by comparing spectra normalized to total AMS organics do not reflect the absolute changes (i.e. net mass production or reduction) in individual organic fragments, which should be independent of the total amount of organic mass remaining in the evaporated droplets. Assuming inorganic sulfate does not react and is not produced significantly in the oxidizing aqueous samples, the organic mass spectra normalized by sulfate mass can be used to determine the absolute changes in individual organic fragments, as presented in Fig. $4 \mathrm{c}$ and f. For the case of aerosol filter extracts, the majority of organic fragments were consumed with only a minor production of $m / z 44$ (or even a small reduction in some samples). By contrast, a significant mass production of $\mathrm{m} / \mathrm{z} 44$ (i.e. organic acids) and consumption of other organic fragments was observed in cloud water. Note that oxidation of S(IV) species (mostly in the form of $\mathrm{HSO}_{3}^{-}$at $\mathrm{pH} 2-7$ ) may be transformed to inorganic sulfate in the oxidized cloud water samples, and hence the sulfate normalized results likely 
represent a lower limit of $m / z 44$ production. However, the S(IV) oxidation is expected to have minimal effects on our observations because the sulfate mass measured by the AMS is the total amount of $\mathrm{S}(\mathrm{IV})$ and $\mathrm{S}(\mathrm{VI})$ species.

Combined with the fractional spectral difference shown in Fig. $4 \mathrm{~b}$ and e, it can be concluded that aqueous oxidation of both aerosol filter extracts and cloud water increased the fractional contribution of organic acids to total organic mass but only oxidized cloud water had significant net mass production of organic acids (see more details in next section). This observation suggests that the organic composition of total cloud organics ( $\mathrm{LV}-\mathrm{CWO}+\mathrm{V}-\mathrm{CWO})$ is different to that of WSOC in aerosols, but their differences cannot be easily distinguished by our technique of atomization and subsequent AMS detection. In particular, we believe that there is a considerable amount of V-CWO in cloud water, which is not AMS-measurable. As described in the next section, this material is involved in aqueous oxidation chemistry to produce additional, lower volatility organic materials in the evaporated droplets.

\subsection{Aqueous oxidation mechanisms: functionalization vs. fragmentation}

Functionalization, fragmentation and oligomerization processes have been recently proposed to describe how aging controls the volatility of aerosol organics and thus their mass loadings in the atmosphere (Jimenez et al., 2009; Kroll et al., 2009). Briefly, oxidative functionalization reduces vapor pressure and enhances $\mathrm{O} / \mathrm{C}$ ratios of organics through addition of oxygenated functional groups to a molecule without breakage of its carbon skeleton. In contrast, fragmentation refers to cleavage of the skeleton and therefore enhances volatility of organic species. Fragmentation and functionalization usually take place together during oxidative processing so that the vapor pressure of products greatly depends on the chemical structure of original molecules as well as the branching ratio of the two oxidative pathways (Kroll et al., 2009). Lastly, oligomerization or formation of high molecular weight organic compounds involves association reactions resulting in an increase of carbon chain length and reduction of volatility.

Figure 5a shows that organic mass profiles (normalized by sulfate mass) of some filter extracts keep decreasing throughout the reaction time regardless of their collection period. From the observed increasing $\mathrm{O} / \mathrm{C}$ ratio (or $f 44$ ) during aqueous oxidation of filter extracts, it can be concluded that significant fragmentation and functionalization of aerosol organics occur simultaneously to produce high-volatility oxygenates that lead to continuous mass loss through evaporation. The general decreasing trend of sulfate-normalized organic signals at $m / z 29,43$ and 44 (Fig. 5b-d) suggests that the total evaporative loss of oxygenated species is faster than their production via aqueous-phase oxidation. The remaining condensed-phase products are mostly organic acids as discussed above. In the WACS 2010 campaign, the Toronto Photo-Oxidation Tube (TPOT) was used to oxidize ambient aerosol particles with a high level of gas-phase $\mathrm{OH}$ radicals at Whistler. It was found that heterogeneous oxidation also enhanced the $\mathrm{O} / \mathrm{C}$ ratio of organic aerosols and reduced the aerosol mass loading by $25 \%$ (Wong et al., 2011; Slowik et al., 2012). Overall, the above findings suggest that the fragmentation pathway plays a dominant role in both aqueous and heterogeneous oxidation to control the overall volatility of atmospheric organic aerosols at Whistler.

For the cloud water samples, organic mass loadings (normalized by sulfate mass) initially increase by $10-30 \%$ and then decline, as shown in Fig. 5a. In principle, functionalization of LV-CWO may explain the initial increase of organic mass and $\mathrm{O} / \mathrm{C}$ ratio if most of the intermediates are nonvolatile in nature (i.e., insignificant fragmentation). However, because of the similarity of the AMS spectra of WSOC in filter extracts and LV-CWO, LV-CWO would be expected to display a similar mass change response to aerosol WSOC during aqueous oxidation. Recall that, as described above, a few identified small carbonyls account for about 8-30\% of water-soluble organic carbon in cloud water collected at Whistler. The contribution of all V-CWO to total cloud organic mass should be higher than this lower limit. Therefore, low-volatility products formed via simultaneous functionalization and fragmentation of V-CWO (i.e., conversion of VCWO to AMS-measurable organics) likely compensate for the mass loss due to oxidation of LV-CWO, leading to the observed net mass enhancement at intermediate stages of oxidation. If this is the case, the functionalization reaction of V-CWO plays a major role to control the overall volatility of cloud organics at the early stage of oxidation (Fig. 5a).

Oxidation of less volatile intermediates, which were produced via aqueous-phase oxidation of V-CWO, further enhances their degree of oxygenation and leads to significant fragmentation at later stages of $\mathrm{OH}$ exposure, resulting in the observed mass reduction (Fig. 5a). Continuous production of less volatile organic acids in the oxidizing cloud water is supported by the growing trend of sulfate-normalized signals at $m / z 44$ (Fig. 5d). Their formation rate, however, slows down at the later stage of $\mathrm{OH}$ exposure, possibly due to the increasing importance of fragmentation reactions of the organic acids (i.e., conversion of large organic acids to more volatile organic compounds and carbon dioxide). Lastly, the sulfatenormalized intensity profiles of $m / z 29$ and 43 (Fig. 5b and c) agree with the changes in organic mass loadings throughout the whole period of aqueous oxidation (Fig. 5a). This observation suggests that less oxygenated carbonyl species also contribute to the enhanced organic mass.

\subsection{Laboratory SOA formation via aqueous oxidation of model organics}

The hypothesis that additional SOA is formed through aqueous-phase oxidation of V-CWO can be demonstrated 
(a)

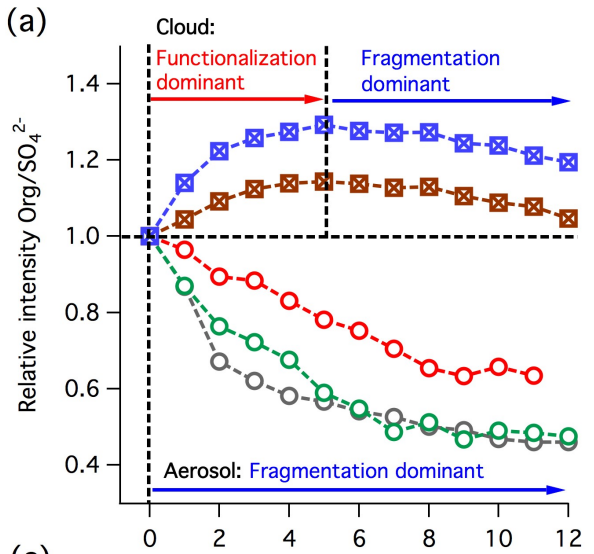

(c)

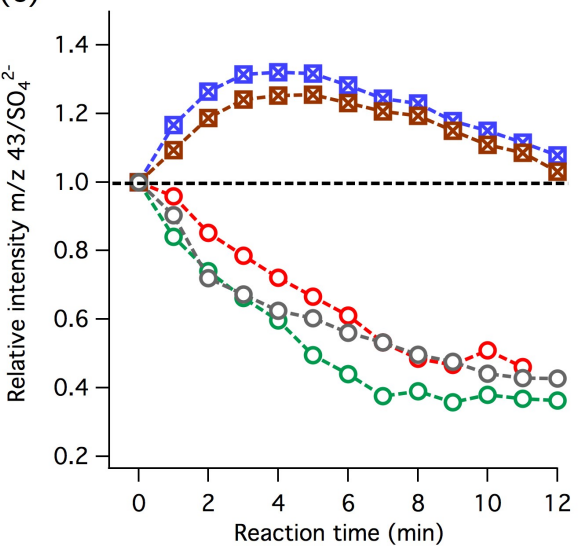

(b)

(d)
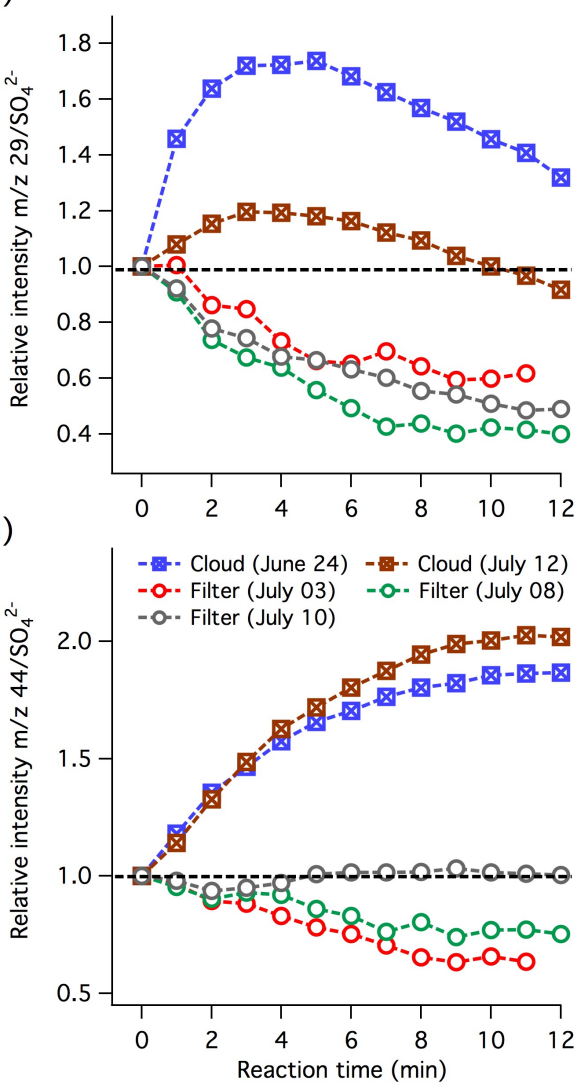

Fig. 5. Time series profiles of sulfate-normalized (a) $\mathrm{Org} / \mathrm{SO}_{4}^{2-}$, (b) $m / z 29 / \mathrm{SO}_{4}^{2-}$, (c) $m / z 43 / \mathrm{SO}_{4}^{2-}$, and (d) $m / z 44 / \mathrm{SO}_{4}^{2-}$ of filter aerosol and cloud water samples due to aqueous-phase $\mathrm{OH}$ oxidation.

using cis-pinonic acid as a model compound. Cis-pinonic acid, a major first-generation product of $\alpha$-pinene ozonolysis, is a moderately water-soluble organic acid with a vapor pressure close to the lower limit of intermediate volatile organic compounds (IVOC) (Donahue et al., 2011; Jimenez et al., 2009). Therefore, it predominantly exists in the gas phase and upon oxidation may give rise to SV-OOA and LVOOA formation in the atmosphere (Donahue et al., 2012; Jimenez et al., 2009). In our approach, cis-pinonic acid solution droplets were generated by atomization and a large portion of cis-pinonic acid was expected to repartition from solution droplets to the gas phase when they were dried, before passing to the AMS for measurement. In this way, it would behave similarly to some V-CWO in our cloud water samples. The aqueous-phase $\mathrm{OH}$ oxidation of cis-pinonic acid was performed in the photochemical reactor $(\sim 1 \mathrm{~L})$ for $5 \mathrm{~h}$ and ammonium sulfate salt was added to the reacting solution as an internal standard for normalization of organic signals. The initial concentrations of $c i s$-pinonic acid and $\mathrm{H}_{2} \mathrm{O}_{2}$ concentrations were $500 \mu \mathrm{M}$ and $13.3 \mathrm{mM}$, respectively. The estimated steady state $\mathrm{OH}$ concentration was $10^{-12}$ to $10^{-13}$ M. Other experimental details can be found in our previous publication (Lee et al., 2011a, b).
Figure 6 shows the AMS organic mass profiles (normalized by sulfate mass) of the cis-pinonic acid solution as it is oxidized. The organic mass initially increased and then decayed, a similar behavior to that observed in the case of cloud water oxidation. Since the organic mass increased by a factor of 2.2 at its maximum, this cannot be realistically achieved by functionalization reactions of the AMS measured cis-pinonic acid alone (e.g., this would require addition of about $10 \mathrm{OH}$ groups, without fragmentation occurring). However, due to the fact that a large fraction of atomized cis-pinonic acid escapes to the gas phase after droplet evaporation and aqueous $\mathrm{OH}$ oxidation of cis-pinonic acid can produce less volatile first- and/or second-generation oxidation products (Jimenez et al., 2009), it is expected that more organic mass can accumulate in the particle phase upon evaporation. Obviously, the second hypothesis more reasonably explains the large increase of organic mass observed. The kinetic profiles of sulfate-normalized organic intensities at $m / z 29,43$ and 44 are also consistent with those observed in the cloud water oxidation (Fig. 6). The high similarity between the case of cis-pinonic acid and cloud organics implies that water-soluble IVOC (e.g., pinonaldehyde, pinic acid and cis-pinonic acid) produced via gas-phase oxidation 


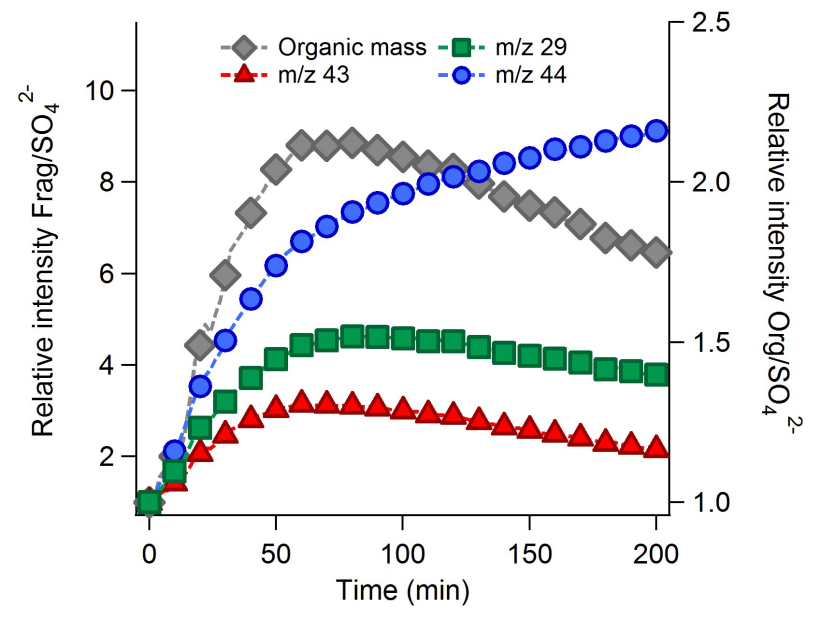

Fig. 6. Time series profiles of sulfate-normalized $\mathrm{Org} / \mathrm{SO}_{4}^{2-}$, $m / z 29 / \mathrm{SO}_{4}^{2-}, m / z 43 / \mathrm{SO}_{4}^{2-}$, and $m / z 44 / \mathrm{SO}_{4}^{2-}$ of $c i s$-pinonic acid $(500 \mu \mathrm{M})$ due to aqueous-phase $\mathrm{OH}$ oxidation.

of monoterpenes may be important aqueous-phase SOA precursors in a biogenic-rich environment. Likewise, Bateman et al. (2011) recently proposed that photolytic processing of cloud droplets can act as a sink of d-limonene derived SOA and can lead to increases in the $\mathrm{O} / \mathrm{C}$ ratio of the processed solution. Although dicarbonyls such as glyoxal and methylglyoxal can lead to formation of highly oxygenated OOA components (Lambe et al., 2011; Lee et al., 2011b; Tan et al., 2010), our offline measurement shows that glyoxal and methylglyoxal only have a small contribution to the WSOC $(\sim 5 \%)$ in our cloud water (Wang et al., 2012). Therefore, aqueous oxidation of these dicarbonyls is unable to explain the enhancement of AMS-measurable organic mass observed in the cloud water experiments.

\section{Conclusions and atmospheric implications}

The chemical characteristics of aerosol filter extracts and cloud water samples collected at the WACS 2010 campaign were analyzed on site using an Aerodyne aerosol mass spectrometer. We report AMS organic spectra of re-aerosolized cloud water and make a direct comparison between the AMS spectra of cloud water and aerosol samples collected at the same location. Sulfate was the major inorganic component in the aerosol samples collected in the non-biogenic period whereas the mass fraction of inorganic nitrate and sulfate were comparable in cloud water, indicating that there was an additional source of inorganic nitrate via cloud processing or absorption from the gas phase such as partitioning of nitric acid $\left(\mathrm{HNO}_{3}\right)$ and hydrolysis of $\mathrm{N}_{2} \mathrm{O}_{5}$. The AMS spectral features of aerosol filter organics show that the fresh biogenic SOA produced in the Whistler forest area was generally less oxygenated than the cloud organics and aged SOA collected in the non-biogenic period, supporting the hypothesis that at- mospheric aging enhances the oxidation state of condensedphase organics.

Fragmentation is the predominant pathway to enhance the overall volatility of organic aerosols throughout the entire aqueous oxidation period. Heterogeneous oxidation of organic aerosols suggests a similar aging mechanism (Donahue et al., 2012; George and Abbatt, 2010; Kroll et al., 2009; Slowik et al., 2012). In particular, heterogeneous OH oxidation of biogenic SOA using TPOT in the same field campaign (equivalent of $\sim 3$ days atmospheric processing) resulted in $\sim 25 \%$ of organic mass loss and produced SOA with O/C values ( 0.7-0.9) (Slowik et al., 2012). Therefore, aqueous and heterogeneous oxidation of biogenic SOA can generate highly oxidized ambient LV-OOA but do not necessarily lead to formation of additional SOA mass.

We also present the first evidence that highly oxidized SOA can be produced via aqueous oxidative processing of ambient volatile cloud water organics (V-CWO). In the atmosphere, the SOA formation first involves the conversion of V-CWO to low volatility CWO (LV-CWO) followed by the evaporative loss of water and volatile organics. Based on the estimated steady state $\mathrm{OH}$ concentration in our experiments, the maximum $\mathrm{OH}$ exposure was equivalent to roughly a week in the atmosphere, assuming an aqueous $\mathrm{OH}$ concentration of $10^{-13} \mathrm{M}$ in cloud droplets during the daytime (Jacob, 1986) and constant cloud water exposure. Given that cloud droplets exist for only minutes at a time, it is clear that the aqueous oxidative processing of $\mathrm{V}$-CWO during each cycle is likely represented by the data observed at the very low $\mathrm{OH}$ exposure region of Figure 5a, where additional organic mass may be produced. Ambient aerosol particles may experience numerous aerosol-cloud cycles within their lifetime, thus increasing their total exposure to aqueous phase processing and thus the importance of V-CWO processing to SOA formation. At very high $\mathrm{OH}$ exposures, LV-CWO can be oxidized to produce higher volatility products as shown in Fig. $5 b$.

This is the first study to oxidize atmospheric water-soluble samples and, by contrast to the aerosol case, we demonstrate that functionalization is the dominant pathway to produce additional SOA mass at the earliest stages of cloud water organic oxidation whereas fragmentation leads to organic mass reduction at a later stage. Kroll et al. (2009) and Donahue et al. (2012) recently suggested that functionalization reactions dominate oxidative aging of reduced organic materials with fragmentation being a minor channel. Fragmentation dominates for moderately oxidized organics (e.g., $\mathrm{O} / \mathrm{C}>0.6$ ). This provides an insight that the significant fraction of V-CWO that contributed to extra organic mass formation may be the less oxidized materials having high to moderate molecular weight. In particular, the water-soluble IVOC produced via gas-phase oxidation of monoterpene such as pinonaldehye, pinic acid and cispinonic acid may be important aqueous-phase SOA precursors in our cloud water samples collected at Whistler and perhaps other biogenic-rich environments. Gelencser and 
Varga (2005) have suggested that organics having Henry's law constant greater than $10^{3} \mathrm{Matm}^{-1}$, such as pinonaldehyde $\left(9 \times 10^{3} \mathrm{M} \mathrm{atm}^{-1}\right)$, can be potential precursors of SOA formed via aqueous processing, depending on their reactivity towards atmospheric oxidants. Nevertheless, V-CWO usually consists of many short chain carbonyls and organic acids (e.g. formic acid and acetic acid) with high $\mathrm{O} / \mathrm{C}$ ratio. Tan et al. (2012) recently demonstrated that aqueous $\mathrm{OH}$ oxidation of acetic acid can produce organic acids with lower volatility, such as glyoxylic, glycolic and oxalic acid, forming additional SOA materials. Thus, the observed mass increase of cloud water oxidation will be the net result of the co-oxidation of small carbonyls and acids and IVOC (Lee et al., 2011a). More detailed chemical characterization of cloud organics and laboratory studies of aqueous oxidation of potential V-CWO will be needed to further improve our understanding of SOA formation via oxidative cloud processing. Lastly, our observation suggests the increasing importance of fragmentation reactions on organic acids at the later stage of both aerosol filter extract and cloud water oxidation with smaller acids as the major condensed-phase products. Since smaller acids tend to form more stable and less volatile salts (e.g., ammonium oxalate) under ambient atmospheric conditions, it would be interesting to further investigate how the salt formation process affects the overall volatility of the organic products produced via aqueous oxidation.

\section{Supplementary material related to this article is available online at: http://www.atmos-chem-phys.net/12/ 7103/2012/acp-12-7103-2012-supplement.pdf.}

Acknowledgements. This work was funded by Environment Canada, Canadian Foundation for Climate and Atmospheric Science (CFCAS) and Natural Science and Engineering Research Council (NSERC). Environment Canada funded the Whistler Aerosol and Cloud Study 2010 through the Clean Air Regulatory Agenda (CARA). Funding was provided through Environment Canada's Grants and Contribution program for JPDA and AKYL (G\&C 1004932). PH acknowledges partial funding from NSF grant AGS\#0847710. Co-operation and support from WhistlerBlackcomb is gratefully acknowledged.

Edited by: F. Keutsch

\section{References}

Aiken, A. C., Decarlo, P. F., Kroll, J. H., Worsnop, D. R., Huffman, J. A., Docherty, K. S., Ulbrich, I. M., Mohr, C., Kimmel, J. R., Sueper, D., Sun, Y., Zhang, Q., Trimborn, A., Northway, M., Ziemann, P. J., Canagaratna, M. R., Onasch, T. B., Alfarra, M. R., Prevot, A. S. H., Dommen, J., Duplissy, J., Metzger, A., Baltensperger, U., and Jimenez, J. L.: O/C and OM/OC ratios of primary, secondary, and ambient organic aerosols with high-resolution time-of-flight aerosol mass spectrometry, Environ. Sci. Technol., 42, 4478-4485, 2008.

Bateman, A. P., Nizkorodov, S. A., Laskin, J., and Laskin, A.: Photolytic processing of secondary organic aerosols dissolved in cloud droplets, Phys. Chem. Chem. Phys., 13, 12199-12212, 2011.

Blando, J. D. and Turpin, B. J.: Secondary organic aerosol formation in cloud and fog droplets: a literature evaluation of plausibility, Atmos. Environ., 34, 1623-1632, 2000.

Canagaratna, M. R., Jayne, J. T., Jimenez, J. L., Allan, J. D., Alfarra, M. R., Zhang, Q., Onasch, T. B., Drewnick, F., Coe, H., Middlebrook, A., Delia, A., Williams, L. R., Trimborn, A. M., Northway, M. J., DeCarlo, P. F., Kolb, C. E., Davidovits, P., and Worsnop, D. R.: Chemical and microphysical characterization of ambient aerosols with the aerodyne aerosol mass spectrometer, Mass Spectrom. Rev., 26, 185-222, 2007.

Carlton, A. G., Turpin, B. J., Altieri, K. E., Seitzinger, S., Reff, A., Lim, H., and Ervens, B.: Atmospheric oxalic acid and SOA production from glyoxal: Results of aqueous photooxidation experiments, Atmos. Environ., 41, 7588-7602, 2007.

Chang, J. L. and Thompson, J. E.: Characterization of colored products formed during irradiation of aqueous solutions containing $\mathrm{H}_{2} \mathrm{O}_{2}$ and phenolic compounds, Atmos. Environ., 44, 541-551, 2010.

Chen, Q., Farmer, D. K., Schneider, J., Zorn, S. R., Heald, C. L., Karl, T. G., Guenther, A., Allan, J. D., Robinson, N., Coe, H., Kimmel, J. R., Pauliquevis, T., Borrmann, S., Pöschl, U., Andreae, M. O., Artaxo, P., Jimenez, J. L., and Martin, S. T.: Mass spectral characterization of submicron biogenic organic particles in the Amazon Basin, Geophys. Res. Lett., 36, L20806, doi:10.1029/2009GL039880, 2009.

Chhabra, P. S., Flagan, R. C., and Seinfeld, J. H.: Elemental analysis of chamber organic aerosol using an aerodyne high-resolution aerosol mass spectrometer, Atmos. Chem. Phys., 10, 4111-4131, doi:10.5194/acp-10-4111-2010, 2010.

De Haan, D. O., Corrigan, A. L., Tolbert, M. A., Jimenez, J. L., Wood, S. E., and Turley, J. J.: Secondary organic aerosol formation by self-reactions of methylglyoxal and glyoxal in evaporating droplets, Environ. Sci. Technol., 43, 8184-8190, 2009.

De Haan, D. O., Hawkins, L. N., Kononenko, J. A., Turley, J. J., Corrigan A. L., Tolbert, M. A., and Jimenez, J. L.: Formation of nitrogen-containing oligomers by methylglyoxal and amines in simulated evaporating cloud droplets, Environ. Sci. Technol., 45, 984-991, 2011.

Donahue, N. M., Epstein, S. A., Pandis, S. N., and Robinson, A. L.: A two-dimensional volatility basis set: 1. organic-aerosol mixing thermodynamics, Atmos. Chem. Phys., 11, 3303-3318, doi:10.5194/acp-11-3303-2011, 2011.

Donahue, N. M., Kroll, J. H., Pandis, S. N., and Robinson, A. L.: A two-dimensional volatility basis set - Part 2: Diagnotics of organic-aerosol evolution, Atmos. Chem. Phys., 12, 615-634, doi:10.5194/acp-12-615-2012, 2012.

Duplissy, J., DeCarlo, P. F., Dommen, J., Alfarra, M. R., Metzger, A., Barmpadimos, I., Prevot, A. S. H., Weingartner, E., Tritscher, T., Gysel, M., Aiken, A. C., Jimenez, J. L., Canagaratna, M. R., Worsnop, D. R., Collins, D. R., Tomlinson, J., and Baltensperger, U.: Relating hygroscopicity and composition of organic aerosol particulate matter, Atmos. Chem. Phys., 11, 11551165, doi:10.5194/acp-11-1155-2011, 2011. 
Ervens, B., Feingold, G., Frost, G., and Kreidenweis, S.: A modeling study of aqueous production of dicarboxylic acids: 1 . Chemical pathways and speciated organic mass production, J. Geophys. Res.-Atmos., 109, D15205, doi:10.1029/2003JD004387, 2004.

Ervens, B., Turpin, B. J., and Weber, R. J.: Secondary organic aerosol formation in cloud droplets and aqueous particles (aqSOA): a review of laboratory, field and model studies, Atmos. Chem. Phys., 11, 11069-11102, doi:10.5194/acp-1111069-2011, 2011.

Fu, T., Jacob, D. J., Wittrock, F., Burrows, J. P., Vrekoussis, M., and Henze, D. K.: Global budgets of atmospheric glyoxal and methylglyoxal, and implications for formation of secondary organic aerosols, J. Geophys. Res.-Atmos., 113, D15303, doi:10.1029/2007JD009505, 2008.

Fu, T., Jacob, D. J., and Heald, C. L.: Aqueous-phase reactive uptake of dicarbonyls as a source of organic aerosol over eastern North America, Atmos. Environ., 43, 1814-1822, 2009.

Galloway, M. M., Chhabra, P. S., Chan, A. W. H., Surratt, J. D., Flagan, R. C., Seinfeld, J. H., and Keutsch, F. N.: Glyoxal uptake on ammonium sulphate seed aerosol: reaction products and reversibility of uptake under dark and irradiated conditions, Atmos. Chem. Phys., 9, 3331-3345, doi:10.5194/acp-9-3331-2009, 2009.

Gelencsér and Varga: Evaluation of the atmospheric significance of multiphase reactions in atmospheric secondary organic aerosol formation, Atmos. Chem. Phys., 5, 2823-2831, doi:10.5194/acp5-2823-2005, 2005.

Gerber, H.: Direct measurement of suspended particulate volume concentration and far-infrared extinction coefficient with a laserdiffraction instrument, Appl. Optics, 30, 4824-4831, 1991.

George, I. J. and Abbatt, J. P. D.: Chemical evolution of secondary organic aerosol from $\mathrm{OH}$-initiated heterogeneous oxidation, Atmos. Chem. Phys., 10, 5551-5563, doi:10.5194/acp-10-55512010, 2010.

Hayden, K. L., Macdonald, A. M., Gong, W., Toom-Sauntry, D., Anlauf, K. G., Leithead, A., Li, S. M., Leaitch, W. R., and Noone, K.: Cloud processing of nitrate, J. Geophys. Res.-Atmos., 113, D18201, doi:10.1029/2007JD009732, 2008.

Heald, C. L., Ridley, D. A., Kreidenweis, S. M., and Drury, E. E.: Satellite observations cap the atmospheric organic aerosol budget, Geophys. Res. Lett., 37, L24808, doi:10.1029/2010GL045095, 2010.

Hennigan, C. J., Bergin, M. H., Dibb, J. E., and Weber, R. J.: Enhanced secondary organic aerosol formation due to water uptake by fine particles, Geophys. Res. Lett., 35, L18801, doi:10.1029/2008GL035046, 2008.

Huang, X. H. H., Ip, H. S. S., and Yu, J. Z.: Secondary organic aerosol formation from ethylene in the urban atmosphere of Hong Kong: a multiphase chemical modeling study, J. Geophys. Res.-Atmos., 116, D03206, doi:10.1029/2010JD014121, 2011.

Hutchings, J. W., Robinson, M. S., McIlwraith, H., Kingston, J. T., and Herckes, P.: The Chemistry of Intercepted Clouds in Northern Arizona during the North American Monsoon Season, Water Air Soil Pollut., 199, 191-202, 2009.

Intergovernmental Panel on Climate Change (IPCC): Climate Change 2007: The physical science basis, contribution of working group I to the fourth assessment report of the IPCC, edited by: Solomon, S., Qin, D., Manning, M., Chen, Z., Marquis, M., Averyt, K. B., Tignor, M., and Miller, H. L., Cambridge Univer- sity Press, Cambridge and New York, 2007.

Jacob, D. J.: Chemistry of $\mathrm{OH}$ in remote clouds and its role in the production of formic acid and peroxymonosulfate, J. Geophys. Res.-Atmos, 91, 9807-9826, 1986.

Jimenez, J. L., Canagaratna, M. R., Donahue, N. M., Prevot, A. S. H., Zhang, Q., Kroll, J. H., DeCarlo, P. F., Allan, J. D., Coe, H., Ng, N. L., Aiken, A. C., Docherty, K. S., Ulbrich, I. M., Grieshop, A. P., Robinson, A. L., Duplissy, J., Smith, J. D., Wilson, K. R., Lanz, V. A., Hueglin, C., Sun, Y. L., Tian, J., Laaksonen, A., Raatikainen, T., Rautiainen, J., Vaattovaara, P., Ehn, M., Kulmala, M., Tomlinson, J. M., Collins, D. R., Cubison, M. J., Dunlea, E. J., Huffman, J. A., Onasch, T. B., Alfarra, M. R., Williams, P. I., Bower, K., Kondo, Y., Schneider, J., Drewnick, F., Borrmann, S., Weimer, S., Demerjian, K., Salcedo, D., Cottrell, L., Griffin, R., Takami, A., Miyoshi, T., Hatakeyama, S., Shimono, A., Sun, J. Y., Zhang, Y. M., Dzepina, K., Kimmel, J. R., Sueper, D., Jayne, J. T., Herndon, S. C., Trimborn, A. M., Williams, L. R., Wood, E. C., Middlebrook, A. M., Kolb, C. E., Baltensperger, U., and Worsnop, D. R.: Evolution of Organic Aerosols in the Atmosphere, Science, 326, 1525-1529, 2009.

Johnson, D., Utembe, S. R., Jenkin, M. E., Derwent, R. G., Hayman, G. D., Alfarra, M. R., Coe, H., and McFiggans, G.: Simulating regional scale secondary organic aerosol formation during the TORCH 2003 campaign in the southern UK, Atmos. Chem. Phys., 6, 403-418, doi:10.5194/acp-6-403-2006, 2006.

Kaul, D. S., Gupta, T., Tripathi, S. N., Tare, V., and Collett, J. L.:Secondary organic aerosol: A comparison between foggy and nonfoggy days, Environ. Sci. Technol., 45, 7307-7313, 2011.

Kroll, J. H., Smith, J. D., Che, D. L., Kessler, S. H., Worsnop, D. R., and Wilson, K. R.: Measurement of fragmentation and functionalization pathways in the heterogeneous oxidation of oxidized organic aerosol, Phys. Chem. Chem. Phys., 11, 8005-8014, 2009.

Lambe, A. T., Onasch, T. B., Massoli, P., Croasdale, D. R., Wright, J. P., Ahern, A. T., Williams, L. R., Worsnop, D. R., Brune, W. H., and Davidovits, P.: Laboratory studies of the chemical composition and cloud condensation nuclei $(\mathrm{CCN})$ activity of secondary organic aerosol (SOA) and oxidized primary organic aerosol (OPOA), Atmos. Chem. Phys., 11, 8913-8928, doi:10.5194/acp11-8913-2011, 2011.

Lee, A. K. Y., Herckes, P., Leaitch, W. R., Macdonald, A. M., and Abbatt, J. P. D.: Aqueous $\mathrm{OH}$ oxidation of ambient organic aerosol and cloud water organics: formation of highly oxidized products, Geophys. Res. Lett., 38, L11805, doi:10.1029/2011GL047439, 2011 a.

Lee, A. K. Y., Zhao, R., Gao, S. S., and Abbatt, J. P. D.: AqueousPhase OH Oxidation of Glyoxal: Application of a Novel Analytical Approach Employing Aerosol Mass Spectrometry and Complementary Off-Line Techniques, J. Phys. Chem. A, 115, 10517 10526, $2011 \mathrm{~b}$.

Lim, Y. B., Tan, Y., Perri, M. J., Seitzinger, S. P., and Turpin, B. J.: Aqueous chemistry and its role in secondary organic aerosol (SOA) formation, Atmos. Chem. Phys., 10, 1052110539, doi:10.5194/acp-10-10521-2010, 2010.

Loeffler, K. W., Koehler, C. A., Paul, N. M., and De Haan, D. O.: Oligomer formation in evaporating aqueous glyoxal and methyl glyoxal solutions, Environ. Sci. Technol., 40, 6318-6323, 2006.

Macdonald, A. M., Leaitch, W. R., Abbatt, J. P. D., Ahlm, L., AlBasheer, W., Betram, A. K., Buller, J., Campuzano-Jost, P., Chan, E., Corbin, J., Cziczo, D., Elford, A., Hayden, K. A., Herckes, 
P., Lee, A. K. Y., Li, S.-M., Liggio, J., Liu, P. S. K., Mihele, C., Noone K.J., Pierce, J. R., Russell, L. M., Toom-Sauntry, D., Schroder, J., Sharma, S., Sheppard, A., Sjostedt, S. J., Slowik, J. G., Strawbridge, K., Stupple, G., Vlasenko, A., Wainwright, C., Wang, Y., Wentzell, J., Wiebe, H. A., and Wong, J. P. S.: An overview of the 2010 WACS2010: Biogenic aerosol formation, mountain flows and CCN, Atmos. Chem. Phys. Discuss., in preparation, 2012.

Munger, J. W., Collett, J. L,. Daube, B. C., and Hoffmann, M. R.: Carboxylic acids and carbonyl compounds in southern California clouds and fogs, Tellus B, 41, 230-242, 1989.

Myriokefalitakis, S., Tsigaridis, K., Mihalopoulos, N., Sciare, J., Nenes, A., Kawamura, K., Segers, A., and Kanakidou, M.: In-cloud oxalate formation in the global troposphere: a 3-D modeling study, Atmos. Chem. Phys., 11, 5761-5782, doi:10.5194/acp-11-5761-2011, 2011.

Ng, N. L., Canagaratna, M. R., Zhang, Q., Jimenez, J. L., Tian, J., Ulbrich, I. M., Kroll, J. H., Docherty, K. S., Chhabra, P. S., Bahreini, R., Murphy, S. M., Seinfeld, J. H., Hildebrandt, L., Donahue, N. M., DeCarlo, P. F., Lanz, V. A., Prévôt, A. S. H., Dinar, E., Rudich, Y., and Worsnop, D. R.: Organic aerosol components observed in Northern Hemispheric datasets from Aerosol Mass Spectrometry, Atmos. Chem. Phys., 10, 46254641, doi:10.5194/acp-10-4625-2010, 2010.

Nguyen, T. B., Lee, P. B., Updyke, K. M., Bones, D. L., Laskin, J., Laskin, A. and Nizkorodov, S. A.: Formation of nitrogenand sulfur-containing light-absorbing compounds accelerated by evaporation of water from secondary organic aerosols, J. Geophys. Res., 117, D01207, doi:10.1029/2011JD016944, 2012.

Noone, K. J., Charlson, R. J., Covert, D. S., Ogren, J. A., and Heintzenberg, J., Cloud Droplets: Solute Concentration is Size Dependent, J. Geophys. Res., 93, 9477-9482, 1988.

Noziere, B., Dziedzic, P., and Cordova, A.: Products and kinetics of the liquid-phase reaction of glyoxal catalyzed by ammonium ions $\left(\mathrm{NH}_{4}^{+}\right)$, J. Phys. Chem. A, 113, 231-237, 2009.

Perri, M. J., Seitzinger, S., and Turpin, B. J.: Secondary organic aerosol production from aqueous photooxidation of glycolaldehyde: Laboratory experiments, Atmos. Environ., 43, 1487-1497, 2009.

Satsumabayashi, H., Nishizawa, H., Yokouchi, Y., and Ueda, H.: Pinonaldehyde and some other organics in rain and snow in central Japan, Chemosphere, 45, 887-891, 2001.

Slowik, J. G., Wong, J. P. S., and Abbatt, J. P. D.: Real-time, controlled $\mathrm{OH}$-initiated oxidation of biogenic secondary organic aerosol, Atmos. Chem. Phys. Discuss., 12, 8183-8224, doi:10.5194/acpd-12-8183-2012, 2012.

Sorooshian, A., Varutbangkul, V., Brechtel, F. J., Ervens, B., Feingold, G., Bahreini, R., Murphy, S. M., Holloway, J. S., Atlas, E. L., Buzorius, G., Jonsson, H., Flagan, R. C., and Seinfeld, J. H.: Oxalic acid in clear and cloudy atmospheres: analysis of data from International Consortium for Atmospheric Research on Transport and Transformation 2004, J. Geophys. Res.-Atmos., 111, D23S45, doi:10.1029/2005JD006880, 2006.

Sorooshian, A., Lu, M., Brechtel, F. J., Jonsson, H., Feingold, G., Flagan, R. C., and Seinfeld, J. H.: On the source of organic acid aerosol layers above clouds, Environ. Sci. Technol., 41, 46474654, 2007.
Tan, Y., Perri, M. J., Seitzinger, S. P., and Turpin, B. J.: Effects of Precursor Concentration and Acidic Sulfate in Aqueous GlyoxalOH Radical Oxidation and Implications for Secondary Organic Aerosol, Environ. Sci. Technol., 43, 8105-8112, 2009.

Tan, Y., Carlton, A. G., Seitzinger, S. P., and Turpin, B. J.: SOA from methylglyoxal in clouds and wet aerosols: Measurement and prediction of key products, Atmos. Environ., 44, 5218-5226, 2010.

Tan, Y., Lim, Y. B., Altieri, K. E., Seitzinger, S. P., and Turpin, B. J.: Mechanisms leading to oligomers and SOA through aqueous photooxidation: insights from $\mathrm{OH}$ radical oxidation of acetic acid and methylglyoxal, Atmos. Chem. Phys., 12, 801-813, doi:10.5194/acp-12-801-2012, 2012.

Volkamer, R., Jimenez, J. L., San Martini, F., Dzepina, K., Zhang, Q., Salcedo, D., Molina, L. T., Worsnop, D. R., and Molina, M. J.: Secondary organic aerosol formation from anthropogenic air pollution: rapid and higher than expected, Geophys. Res. Lett., 33, L17811, doi:10.1029/2006GL026899, 2006.

Volkamer, R., Martini, F. S., Molina, L. T., Salcedo, D., Jimenez, J. L., and Molina, M. J.: A missing sink for gas-phase glyoxal in Mexico City: Formation of secondary organic aerosol, Geophys. Res. Lett., 34, L19807, doi:10.1029/2007GL030752, 2007.

Volkamer, R., Ziemann, P. J., and Molina, M. J.: Secondary Organic Aerosol Formation from Acetylene $\left(\mathrm{C}_{2} \mathrm{H}_{2}\right)$ : seed effect on SOA yields due to organic photochemistry in the aerosol aqueous phase, Atmos. Chem. Phys., 9, 1907-1928, doi:10.5194/acp9-1907-2009, 2009.

Wang, Y., Macdonald, A. M., Leaitch, W. R., Hutchings, J. W and P. Herckes, Cloud Chemistry during the 2010 Whistler aerosol and cloud study, in preparation, 2012.

Wong, J. P. S., Lee, A. K. Y., Slowik, J. G., Cziczo, D. J., Leaitch, W. R., Macdonald, A., and Abbatt, J. P. D.: Oxidation of ambient biogenic secondary organic aerosol (SOA) by hydroxyl radicals: effects on cloud condensation nuclei activity, Geophys. Res. Lett., 38, L22805, doi:10.1029/2011GL049351, 2011.

Yu, G., Bayer, A. R., Galloway, M. M., Korshavn, K. J., Fry, C. G., and Keutsch, F. N.: Glyoxal in aqueous ammonium sulfate solutions: products, kinetics and hydration effects, Environ. Sci. Technol., 45, 6336-6342, 2011.

Zhang, Q., Jimenez, J. L., Canagaratna, M. R., Allan, J. D., Coe, H., Ulbrich, I., Alfarra, M. R., Takami, A., Middlebrook, A. M., Sun, Y. L., Dzepina, K., Dunlea, E., Docherty, K., DeCarlo, P. F., Salcedo, D., Onasch, T., Jayne, J. T., Miyoshi, T., Shimono, A., Hatakeyama, S.,Takegawa, N., Kondo, Y., Schneider, J., Drewnick, F., Borrmann, S., Weimer, S., Demerjian, K., Williams, P., Bower, K., Bahreini, R., Cottrell, L., Griffin, R. J., Rautiainen, J., Sun, J. Y., Zhang, Y. M., and Worsnop, D. R.: Ubiquity and dominance of oxygenated species in organic aerosols in anthropogenically-influenced Northern Hemisphere midlatitudes, Geophys. Res. Lett., 34, L13801, doi:10.1029/2007GL029979, 2007.

Zhao, R., Lee., A. K. Y., and Abbatt, J. P. D.: Investigation of aqueous-phase photooxidation of glyoxal and methylglyoxal by aerosol chemical ionization mass spectrometry: observation of hydroxyhydroperoxide formation, J. Phys. Chem. A, 116, 62536263, 2012. 